\title{
$\beta$-Thalassemia and renal complications. A narrative review of pathophysiologic mechanisms
}

\author{
Christos Demosthenous $^{1 *}$, Perla Eleftheriou ${ }^{2}$, Chrysa Apostolou ${ }^{3}$, Pantelis Sarafidis ${ }^{4}$, Vassilios Perifanis ${ }^{5}$ and Efthimia Vlachaki ${ }^{3}$ \\ ${ }^{1}$ Department of Hematology and HCT Unit, General Hospital of Thessaloniki “George Papanicolaou”, Thessaloniki, Greece \\ ${ }^{2}$ Department of Haematology, University College London, London, UK \\ ${ }^{3}$ Adults Thalassemia Unit, Second Department of Internal Medicine, Aristotle University, Hippokration Hospital, Thessaloniki, Greece \\ ${ }^{4}$ Department of Nephrology, Hippokration Hospital, Aristotle University of Thessaloniki, Thessaloniki, Greece \\ ${ }^{5}$ First Propedeutic Department of Internal Medicine, University General Hospital of Thessaloniki AHEPA, Thessaloniki, Greece
}

\begin{abstract}
$\beta$-thalassemia are a group of recessively autosomal inherited disorders of haemoglobin synthesis where in mutations of the $\beta$-globin gene lead to various degrees of defective $\beta$-chain production, an imbalance in $\alpha / \beta$-globin chain synthesis, ineffective erythropoiesis, and anaemia. Improved survival in thalassaemic patients has led to the emergence of previously unrecognized complications, such as renal disease. Renal disease is considered the $4^{\text {th }}$ cause of morbidity among patients with transfusion dependent thalassemia. Chronic anaemia, hypoxia and iron overload are the main mechanisms implicated in development of renal injury, whereas several studies suggested also a contributive role of iron chelators. Kidney disease may develop through progressing renal tubular and glomerular damage; thus, its early recognition and prevention is important in order to prevent and/or reverse deterioration. This review will provide an insight on the involved mechanisms implicated in kidney disease in thalassaemic patients and will discuss the updates on diagnosis and prevention of renal complications in thalassemia.
\end{abstract}

\section{Introduction}

$\beta$-thalassemia syndromes are the most common inherited monogenic disorders worldwide. They are heterogenous disorders caused by reduced or absent $\beta$-globin synthesis, a major component of adult haemoglobin $\mathrm{A}(\mathrm{HbA}, \alpha 2 \beta 2)$ leading to imbalance of the globin chains [1]. Consequently, $\beta$-thalassemia leads to reduced haemoglobin production and accumulation of $\alpha$-globins which form insoluble hemi chromes [2]. The former causes microcytic, hypochromic anaemia; the latter is associated with oxidative stress, ineffective erythropoiesis and haemolytic anaemia $[3,4]$. The clinical and haematological spectrum of $\beta$-thalassemia disease ranges from mild to clinically overt conditions including transfusion dependent (TDT) $\beta$-thalassemia major (TM) and non-transfusion dependent (NTDT) $\beta$-thalassemia intermedia (TI) or thalassemia minor (TMin) [5].

Thalassemia syndromes are prevalent in the Mediterranean, Africa and Southeast Asia [6]. Although they present a significant public health concern for poorer countries, population movements from countries where thalassemia is prevalent have also led to an increased number of patients affected in developed countries [7]. At least $20.7 \%$ of the world population carry a $\beta$-thalassemia variant, whereas annually approximately 40000 children are born with $\beta$-Thalassemia [8].

In recent years, mainly in developed countries, the prognosis of $\beta$-thalassemia has improved due to blood transfusion, iron chelation therapy and the advances in the knowledge of the disease. In addition, the numbers of new-borns with $\beta$-thalassemia have been limited in Western societies due to introduction of screening programs.

Following the improved survival noted for $\beta$-thalassemia in recent years, many patients experience dysfunctions in several systems, including cardiopulmonary disorders, endocrine organ diseases, liver dysfunction and thromboses in different vascular beds [9]. Further, the advances in the management of patients with $\beta$-thalassemia translated into improved patient survival has allowed previously unrecognized renal complications to emerge. The effect of thalassemia on the kidney has not been extensively evaluated. This review will discuss current knowledge and future perspectives in the field.

\section{Materials and methods}

A bibliographical research was carried out in PubMed searching for articles published in the last decades, in order to provide a narrative review on the pathophysiological mechanisms of renal disease in $\beta$-thalassemia.

\section{Epidemiology}

Information on the epidemiology of renal complications in $\beta$-thalassemia is limited. Cross-sectional studies in various thalassemia groups from five thalassemia centres in North America have shown reduced creatinine clearance in $7.8 \%$, and albuminuria in up to $59 \%$ of patients [10]. More recent studies identified renal dysfunction in $1.8 \%$ of TDT patients, whereas renal disease was classified as the 4 th most common cause of morbidity (4\%) after endocrine (44.7\%),

${ }^{\star}$ Correspondence to: Christos Demosthenous, Department of Hematology and HCT Unit, General Hospital of Thessaloniki "George Papanicolaou", Thessaloniki, Exohi, Thessaloniki 57010, Greece, E-mail: christosde@msn.com

Key words: $\beta$-Thalassemia, renal complications, iron chelators

Received: August 19, 2018; Accepted: August 27, 2018; Published: August 31, 2018 
cardiovascular $(41.3 \%)$ and hepatic $(40.5 \%)$ disease in the same patient population $[11,12]$.

However, there are currently no data from large observational cohorts on the prevalence of chronic kidney disease (CKD) following contemporary definitions in patients with $\beta$-thalassemia.

\section{Renal manifestations of $\boldsymbol{\beta}$-thalassemia}

In the following lines the most common pathophysiologic and clinical manifestations of renal disease in $\beta$-thalassemia patients are discussed. The etiology, pathogenetic mechanisms involved, and possible evaluation, including emerging biomarkers are presented in Table 1.

\section{Tubular dysfunction}

Evidence of tubular dysfunction among patients with $\beta$-thalassemia, were initial described about 2 decades ago by Ong-ajyooth et al [13]. Since then, several studies confirmed and evaluated further tubular function in $\beta$-thalassemia (Table 2) Up to $60 \%$ of patients with TDT have been reported to develop signs of tubular dysfunction [14]. Common signs of tubulopathy, such as proteinuria (8.6\%), hypercalciuria (12.9\%), phosphaturia (9.2\%), hyperuricosuria (38\%), magnesiumuria $(8.6 \%)$, and increased excretion of $\beta 2$-microglobin ( $\beta 2 \mathrm{M})(13.5 \%)$ was demonstrated in a TDT Iranian population [15].
Early recognition of renal dysfunction is of great importance both for intervening in a timely manner and for improving prognosis. Therefore, in recent years several products produced and released by proximal tubular cells as measurable proteins in a variety of renal diseases have been tested, as possible valid biomarkers of renal injury. Such proteins include N-Acetyl-beta-D-glycosaminidase (NAG), neutrophil gelatinase-associated lipocalin (NGAL), Kidney Injury Molecule-1 (KIM-1), Liver-type Fatty Acid-Binding Protein (L-FABP) and Interleukin-8 (IL-8), all of which were studied mainly in children and younger patients with TM [16-18]. Further studies are needed to evaluate the significance of these biomarkers as predictors of renal disease in thalassemia patients.

Tubular dysfunction among patients with $\beta$-thalassemia has been related to iron overload, chronic anaemia, as well as deferoxamine (DFO) toxicity [19-22]. The mechanism of iron overload-associated renal damage has not been fully elucidated. Non-transferrin iron can lead to organelle membrane dysfunction and subsequent cell injury/death. Iron-catalyse generation of reactive oxygen species (ROS) is responsible for initiating the peroxidative reaction. The possible association of oxidative stress and its impact on nitric oxide (NO) metabolism in iron overload associated renal injury was investigated through a randomized study in rats. In this study, animals were assigned into Fe-loaded (given $500 \mathrm{mg}$ elemental iron/kg body weight as iron dextran; IV), Fe-depleted

Table 1. Renal disease in $\beta$-Thalassemia

\begin{tabular}{|c|c|c|c|}
\hline Renal manifestation & Etiology & Mechanism & Evaluation/Biomarkers \\
\hline Haematuria & Nephrolithiasis & $\begin{array}{l}\text { Hypercalciuria, hyperuricosuria, cystinuria, struvite } \\
\text { stones }\end{array}$ & Dipstick urinalysis \\
\hline \multirow{6}{*}{ Tubular dysfunction } & Chronic anaemia/hypoxia & $\begin{array}{l}\text { Oxidative stress, lipid peroxidation, endothelial damage } \\
\text { and loss of peritubular capillaries }\end{array}$ & \multirow{6}{*}{$\begin{array}{c}\text { Serum } \beta 2-\mathrm{M} \\
\text { Urine calcium/creatinine } \\
\text { Urine } \beta 2-\mathrm{M} / \text { creatinine } \\
\text { Urinary NAG } \\
\text { Urinary NAGL } \\
\text { Urinary a1-microglobulin } \\
\text { Urinary RBP }\end{array}$} \\
\hline & Iron overload & Oxidative stress, lipid peroxidation & \\
\hline & Iron chelators & Nephrotoxicity & \\
\hline & $\begin{array}{l}\text { Aminoglycoside, intravenous } \\
\text { radiocontrast agents, NSAIDs }\end{array}$ & $\begin{array}{l}\text { Cytotoxicity, renal vasoconstriction, acute tubular } \\
\text { necrosis. }\end{array}$ & \\
\hline & $\beta$-lactames & $\begin{array}{l}\text { Mitochondrial dysfunction, lipid peroxidation, acute } \\
\text { tubular necrosis }\end{array}$ & \\
\hline & $\begin{array}{l}\text { Ampicillin, ciprofloxacin, } \\
\text { sulphonamides }\end{array}$ & Crystal precipitation within the distal tubular lumen & \\
\hline \multirow{7}{*}{ Glomerular dysfunction } & Chronic anaemia/hypoxia & Reduced vascular resistance, elevated RPF & \multirow{6}{*}{$\begin{array}{c}\text { Urine dipstick } \\
\text { Serum creatinine } \\
\text { Urine protein/creatinine } \\
\text { Serum cystatin } \\
\mathrm{CrCl} \\
\text { eGFR }\end{array}$} \\
\hline & & $\begin{array}{c}\text { Damage and loss of peritubular capillaries, epithelial- } \\
\text { mesenchymal trans differentiation of tubular } \\
\text { cells to myofibroblasts, tubulointerstitial injury, } \\
\text { glomerulosclerosis }\end{array}$ & \\
\hline & Iron overload & $\begin{array}{c}\text { Damage and loss of peritubular capillaries, epithelial } \\
\text { mesenchymal trans differentiation of tubular } \\
\text { cells to myofibroblasts, tubulointerstitial injury, } \\
\text { glomerulosclerosis }\end{array}$ & \\
\hline & Infections (e.g. HIV, HCV, HBV) & Glomerulonephritis & \\
\hline & Iron chelators & $\begin{array}{l}\text { Relative iron depletion, mitochondrial dysfunction in } \\
\text { tubular cells, tubuloglomerular feedback, vasoconstriction } \\
\text { of the afferent arteriole }\end{array}$ & \\
\hline & NSAIDs, COX-2 inhibitors & Vasoconstriction of the afferent arteriole & \\
\hline & ACE inhibitors, ARBs & Vasodilation of the afferent and efferent arterioles & \\
\hline \multirow{4}{*}{ Nephrolithiasis } & $\begin{array}{l}\text { Vitamin } \mathrm{D} \text {, calcium supplementation, } \\
\text { deferasirox, tubular dysfunction }\end{array}$ & Hypercalciuria, calcium stones & \multirow{4}{*}{$\begin{array}{l}\text { Urine dipstick } \\
\text { Serum electrolytes } \\
\text { Serum creatinine } \\
\text { ine collection Radiographic studies }\end{array}$} \\
\hline & Tubular dysfunction & Cystinuria, cystine stones & \\
\hline & $\begin{array}{l}\text { Splenectomy increased red cell } \\
\text { turnover, tubular dysfunction }\end{array}$ & Hyperuricosuria, uric acid stones & \\
\hline & $\begin{array}{l}\text { Urinary tract infections by urease- } \\
\text { producing bacteria (e.g. Proteus } \\
\text { spp, Klebsiella spp, S.epidermidis, } \\
\text { Mycoplasma spp, yeast species) }\end{array}$ & Struvite stones & \\
\hline
\end{tabular}

B2M: $\beta 2$ micro globulin; NAG: N-Acetyl-beta-D-glycosaminidase; NAGL: neutrophil gelatinase-associated lipocalin; RBP: Retinol binding protein; RPF: Renal plasma flow; HIV: Human immunodeficiency virus; HBV: Hepatitis B virus; HCV: Hepatitis C virus; NSAIDs: Nonsteroidal anti-inflammatory drugs; COX2: Cyclooxygenase-2; ACE: Angiotensin-converting enzyme; ARBs: Angiotensin receptor blockers; $\mathrm{CrCl}$ : Creatinine clearance; eGFR: estimated glomerular filtration rate 
Table 2. Studies indicated or no tubular dysfunction in patients with $\beta$-thalassemia

\begin{tabular}{|c|c|c|c|c|c|c|}
\hline Authors & Study type & $\begin{array}{l}\text { Number of } \\
\text { patients }\end{array}$ & $\begin{array}{l}\text { Age } \\
\text { (years) }\end{array}$ & $\begin{array}{l}\text { Chelation } \\
\text { therapy }\end{array}$ & Biomarkers & Results-Conclusions \\
\hline $\begin{array}{l}{ }_{20}^{18} \text { Koliakos et al, } \\
2003\end{array}$ & observational & $\begin{array}{l}91 \text { TM with } \\
\text { no evidence of } \\
\text { renal disease }\end{array}$ & $17.2 \pm 7.2$ & DFO & $\begin{array}{l}\text { Urine NAG } \\
\text { Urine IgG } \\
\text { Urine albumin } \\
\text { Urine } \beta 2 \mathrm{M} \\
\text { Serum ferritin }\end{array}$ & $\begin{array}{l}\text { - high incidence of renal proximal tubular dysfunction. } \\
\text {-iron overload as the main cause of this dysfunction }\end{array}$ \\
\hline $\begin{array}{l}{ }^{87} \text { Papassotiriou } \\
\text { et al, } 2010\end{array}$ & observational & $\begin{array}{l}150 \mathrm{TM} \\
\text { with no } \\
\text { evidence of } \\
\text { renal disease }\end{array}$ & $\begin{array}{l}29.2(6.4- \\
44.2)\end{array}$ & DFX & $\begin{array}{l}\text { Plasma NGAL } \\
\text { Cys C } \\
\text { NT-proBNP } \\
\text { ferritin }\end{array}$ & $\begin{array}{l}\text { Cys } C \text { concentration may be influenced by } \\
\text { hemodynamic parameters as a result of therapy with DFX. Any changes } \\
\text { in cys } C \text { do not reflect renal impairment }\end{array}$ \\
\hline $\begin{array}{l}{ }^{16} \text { Jalali et al, } \\
2011\end{array}$ & $\begin{array}{l}\text { case-control } \\
\text { study }\end{array}$ & $\begin{array}{l}140 \mathrm{TM} \\
\text { with no } \\
\text { evidence of } \\
\text { renal disease }\end{array}$ & $7-16$ & DFO & $\begin{array}{l}\text { urine NAG } \\
\text { blood sample for biochemical and } \\
\text { ferritin tests }\end{array}$ & $\begin{array}{l}\text { - Kidney dysfunction in thalassemia increases with increasing age, } \\
\text { duration, and levels of blood transfusion and hypercalciuria. } \\
\text { - The presence } \\
\text { of severe renal dysfunction in thalassaemic patients should be } \\
\text { investigated using sensitive and specific tests, mainly NAG, to prevent } \\
\text { progress }\end{array}$ \\
\hline $\begin{array}{l}{ }^{15} \text { Mohkam et al, } \\
2008\end{array}$ & $\begin{array}{l}\text { cross-sectional } \\
\text { study }\end{array}$ & $\begin{array}{l}103 \mathrm{TM} \\
\text { with no } \\
\text { evidence of } \\
\text { renal disease }\end{array}$ & $\begin{array}{l}12.5+/- \\
5.53\end{array}$ & DFO & $\begin{array}{l}\text { Urine } \\
\text { sodium }(\mathrm{Na}), \text { potassium }(\mathrm{K}), \\
\text { calcium }(\mathrm{Ca}), \\
\text { creatinine }(\mathrm{Cr}), \text { phosphate, uric } \\
\text { acid (UA), NAG and amino acids }\end{array}$ & $\begin{array}{l}\text { Urinary NAG excretion } \\
\text { can be a reliable index of the tubular } \\
\text { toxicity and a possible predictor of proteinuria, aminoaciduria and } \\
\text { eventual renal impairment in these patients. }\end{array}$ \\
\hline $\begin{array}{l}{ }^{38} \text { Michelakakis et } \\
\text { al, } 1997\end{array}$ & $\begin{array}{l}\text { case-control } \\
\text { study }\end{array}$ & $\begin{array}{l}36 \mathrm{TM} \\
\text { with no } \\
\text { evidence of } \\
\text { renal disease }\end{array}$ & $5-22$ & DFO & $\begin{array}{l}\text { urine specimens } \\
\text { Urine NAG } \\
\text { a-Mannosidase } \\
\text { ferritin }\end{array}$ & $\begin{array}{l}\text { Iron overload resulted in increased urinary levels of the lysosomal } \\
\text { enzyme NAG. } \\
\text { Reduction of iron load, achieved by regular DFO infusion, resulted in } \\
\text { normalization of the urinary enzyme levels. }\end{array}$ \\
\hline $\begin{array}{l}{ }^{30} \text { Smolkin et al, } \\
2008\end{array}$ & $\begin{array}{l}\text { case-control } \\
\text { study }\end{array}$ & $\begin{array}{l}37 \mathrm{TM} \text { and } \\
11 \mathrm{TI}\end{array}$ & $2.4-27$ & DFO & $\begin{array}{l}\text { Urine } \\
\text { and blood samples } \\
\text { Urine NAG }\end{array}$ & $\begin{array}{l}\text { Renal tubular function is impaired in children with TM and TI. It is not } \\
\text { known } \\
\text { whether these functional abnormalities would have any long-term effects } \\
\text { on the patients. }\end{array}$ \\
\hline $\begin{array}{l}{ }^{22} \text { Kalman et al, } \\
2005\end{array}$ & $\begin{array}{l}\text { case-control } \\
\text { study }\end{array}$ & 32 Tmin & $5.8+/-3.1$ & - & $\begin{array}{l}\text { Urinary calcium excretion zinc } \\
\text { glucosuria }(\mathrm{mg} / \mathrm{dL}) \\
\beta 2 \mathrm{M}(\mathrm{mg} / \mathrm{dL}) \\
\mathrm{NAG} \\
\text { sodium, magnesium } \\
\text { uric acid and tubular } \\
\text { phosphorus reabsorption }\end{array}$ & $\begin{array}{l}\text { Renal tubular dysfunction has not been determined in children with } \\
\text { TMin. }\end{array}$ \\
\hline $\begin{array}{l}{ }^{44} \text { Tantawy et al, } \\
2014\end{array}$ & $\begin{array}{l}\text { cross- } \\
\text { sectional, case- } \\
\text { control study }\end{array}$ & $\begin{array}{l}66 \mathrm{TM} \text { and } \\
26 \mathrm{TI}\end{array}$ & $2.5-16$ & DFP & $\begin{array}{l}\text { Serum ferritin, bicarbonate, } \\
\text { plasma osmolality and urinary } \\
\text { total proteins, microalbuminuria, } \\
\text { NAG, RBP, } \alpha-1 \text { micro globulin, } \\
\text { bicarbonate, osmolality, creatinine } \\
\text { clearance }(\mathrm{CrCl})\end{array}$ & $\begin{array}{l}\text { Asymptomatic renal dysfunctions are prevalent in young } \beta \text {-TM and } \beta \text {-TI } \\
\text { patients that necessitate regular screening }\end{array}$ \\
\hline $\begin{array}{l}{ }^{121} \text { Aydinok et al, } \\
1999\end{array}$ & $\begin{array}{l}\text { case-control } \\
\text { study }\end{array}$ & $40 \mathrm{TM}$ & $6-24$ & DFO & Urinary NAG creatinine, zinc & $\begin{array}{l}\text { Urinary NAG indices }(\mathrm{U} / \mathrm{g} \mathrm{Cr}) \text { were significantly higher in the patients } \\
\text { compared to controls. Urinary zinc excretion was correlated with the } \\
\text { urinary NAG indices. }\end{array}$ \\
\hline $\begin{array}{l}{ }^{14} \text { Ong-ajyooth et } \\
\text { al, } 1998\end{array}$ & $\begin{array}{l}\text { case-control } \\
\text { study }\end{array}$ & $\begin{array}{l}95 \text { beta-thal/ } \\
\mathrm{Hb} \mathrm{E}\end{array}$ & na & na & $\begin{array}{l}\text { Urine NAG, } \beta 2 \mathrm{M} \\
\text { Plasma and urine MDA }\end{array}$ & $\begin{array}{l}\text { This is the first report of renal tubular defects found associated with beta- } \\
\text { thal/Hb E disease. The mechanism leading to the damage is not known } \\
\text { but it might be related to increased oxidative stress secondary to tissue } \\
\text { deposition of iron, as indicated by the raised levels of serum and urine } \\
\text { MDA. }\end{array}$ \\
\hline $\begin{array}{l}{ }^{26} \text { Patsaoura et al, } \\
2014\end{array}$ & $\begin{array}{l}\text { case-control } \\
\text { study }\end{array}$ & $35 \mathrm{TI}$ & $8-63$ & - & $\begin{array}{l}\text { Plasma NGAL, } \\
\text { STfR, NTBI, } \\
\text { Cys C, } \beta 2 \mathrm{M} \text {, } \\
\text { hs-CRP }\end{array}$ & $\begin{array}{l}\text { The increased NGAL levels reported for the first time in TI patients in } \\
\text { agreement with the elevated expression of NGAL observed in TI mouse } \\
\text { models. } \\
\text { The induction of NGAL may represent either a survival response, } \\
\text { facilitating the survival of the less damaged } \\
\text { thalassaemic erythroid precursors, or a consequence of the abnormal iron } \\
\text { regulation in TI. }\end{array}$ \\
\hline $\begin{array}{l}{ }^{27} \text { Roudkenar et } \\
\text { al, } 2008\end{array}$ & $\begin{array}{l}\text { case-control } \\
\text { study }\end{array}$ & $\begin{array}{l}25 \text { adult's TM } \\
\text { and } \\
9 \text { paediatric TM }\end{array}$ & $\begin{array}{l}24.33 \pm \\
7.09 \text { and } \\
8.28 \pm \\
1.49\end{array}$ & na & $\begin{array}{l}\text { Plasma NGAL with PCR and } \\
\text { ELISA }\end{array}$ & $\begin{array}{l}\text { - In all adult cases, except one sample, NGAL protein was expressed } \\
\text { more compared } \\
\text { to the controls } \\
\text { - Positive correlation with ferritin } \\
\text { - Negative correlation with sex, age } \\
\text { - NGAL upregulation was not found in paediatric } \beta \text { - thalassemia patients. } \\
\text { Iron overload and oxidative status in } \beta \text {-thalassemia patients induce } \\
\text { NGAL/Lcn2 expression. Upregulation of NGAL in this disorder may } \\
\text { play a beneficial role in decreasing ROS or chelating iron. Obviously, } \\
\text { chelating of iron is one of the major therapeutic goals in b-thalassemia. }\end{array}$ \\
\hline
\end{tabular}

TM: Thalassemia major; TI: Thalassemia intermedia; TMin: Thalassemia minor; DFO: Deferoxamine; DFX: Deferasirox NAG: N-Acetyl-beta-D-glucosaminidase; $\beta 2 \mathrm{M}$ : $\beta 2$ micro globulin; NAGL: Neutrophil gelatinase-associated lipocalin; IgG: Immunoglobulin G; Cys C: Cystatin C; NT-proBNP: N-terminal pro b-type natriuretic peptide; RBP: Retinol binding protein; MDA: malondialdehyde; STfR: Soluble Transferrin Receptor; NTBI: Non-transferrin-bound serum iron; hs-CRP: high-sensitivity C-reactive protein; PCR: Polymerase chain reaction; ELISA: Enzyme-linked Immunosorbent Assay; Lcn-2: Lipocalin-2; ROS: Reactive oxygen species 
(given an iron-free diet for 20 weeks), and control groups. Chronic iron deposition in proximal tubules, glomeruli and interstitium was associated with significant glomerulosclerosis, tubular atrophy, and interstitial fibrosis [23]. Iron staining in the distal tubules was negligible, but iron overload resulted in iron deposition in the glomeruli and proximal tubules with various renal lesions and evidence of increased ROS activity, enhanced ROS-mediated inactivation and sequestration of NO. Iron depletion was associated with reduced malondialdehyde (MDA) and tissue nitro tyrosine abundance, increased urinary NO metabolite (NOx) excretion, normal NO synthase (NOS) expression and absence of renal injury. The iron overload-induced toxicity is supported by clinical studies demonstrating concordance between serum ferritin levels and markers of tubular injury. At the same time, chelation therapy was associated with reversal of toxicity. An initial study from Greece including 36 patients aged 5-22 years old with TM showed a significantly higher urinary excretion of NAG in patients with poor compliance to DFO and serum ferritin $>3,000 \mathrm{ng} / \mathrm{ml}$ as compared to regularly chelated patients with serum ferritin $<3,000 \mathrm{ng} / \mathrm{ml}(2.86$ \pm 0.287 vs. $2.37 \pm 0.32 \mathrm{nmol} / \mathrm{mg}$ creatinine $/ \mathrm{h}, \mathrm{p}<0.05$ ) [24]. Similar results were observed in a second Greek study with 91 TM patients, aged 5-65 years and on DFO chelation. However, urine markers did not correlate with age, indicating that DFO treatment was not related to renal dysfunction [25].

Anaemia and associated potential chronic hypoxia could also lead to activation of the oxidative stress, lipid peroxidation and lead to tubular functional abnormalities [26,27]. Moreover, hypoxia per se induces differentiation of tubular cells to myofibroblasts, while at the same time it activates fibroblasts, changes the extracellular matrix metabolism of renal cells and leads to the obliteration of peritubular capillaries [28-30]. Relationship between the degree of anaemia and tubular dysfunction markers has been demonstrated in a study performed in a paediatric population of 104 patients with $\beta$-thalassemia of various disease severity. The patients were divided into three groups: severe anaemia [haematocrit $(\mathrm{Hct})<25 \%$ ], hyper transfusion program and DFO treatment, and moderate anaemia (Hct> 25\%). Patients with severe anaemia had significantly higher low-molecular weight proteinuria and malondialdehyde (MDA, an indicator of lipid peroxidation), and lower urine osmolarity than those with moderate anaemia. Severity of the abnormalities were least severe in patients on hyper transfusion and DFO therapy [22].

Etiology of the precise distribution of iron deposits in the renal tubular system has not been fully clear. In parallel, kidney biopsies to delineate such early deposits are impractical because of the procedural risk and the significant patient discomfort. Nowadays, kidney magnetic resonance imaging (MRI) is essential for non-invasive evaluation of renal iron overload. Eighty-three patients suffered from TM (mean age 24.7 years) and 37 patients with TI (mean age 28.8 years) were enrolled in an interesting study performed in Tehran, Iran. The mean transfusion duration was 21.8 days, while $57.5 \%$ of patients were splenectomised. All patients received iron chelation therapy (mean therapy duration 21.8 years) with variable compliance. The results showed statistically significant, but moderate correlation between serum ferritin and kidney $\mathrm{T} 2^{\star}$ relaxation (correlation coefficient $=-0.446, \mathrm{P}<0.001$ ). The non-significant correlation of liver or heart MRI T2* relaxation time with serum ferritin highlights the important role of kidney MRI on iron load assessment [31].

In addition to the above, splenectomy was proved to be an independent risk factor for tubular abnormalities. A cross-sectional, case-control study reported data among 40 splenectomised and 26 non-splenectomised patients with TM, aged 2.5 -13 years (mean 6 years). Increased levels of NAG $(32 \pm 14.3 \mathrm{Ug} / \mathrm{g}$ creatinine, $\mathrm{p}<0.01 \mathrm{vs}$. $18.3 \pm 15.2 \mathrm{Ug} / \mathrm{g}$ creatinine, $\mathrm{p}<0.01), \alpha-1$ macroglobulin $(27.5 \pm 13.6$ $\mathrm{mg} / \mathrm{g}$ creatinine, $\mathrm{p}<0.01$ vs. $13 \pm 8.5 \mathrm{mg} / \mathrm{g}$ creatinine, $\mathrm{p}<0.01)$ and also marked elevation of serum ferritin $(683 \pm 160 \mathrm{ng} / \mathrm{ml}, \mathrm{p}<0.01$ vs. 483 $\pm 227 \mathrm{ng} / \mathrm{ml}, \mathrm{p}<0.01$ ) were found more frequently in splenectomised than in non-splenectomised patients [32].

Interestingly, improved renal function was illustrated in patients with TDT after curative hematopoietic stem-cell transplantation (HSCT). When comparing 29 children with TM who had undergone HSCT with 39 children of the same age and similar disease severity but who had not experienced HSCT, parameters of tubule function were better in patients that had undergone HSCT, as demonstrated by urine protein level $(0.36 \mathrm{mg} / \mathrm{mg}$ creatinine vs $3.03 \mathrm{mg} / \mathrm{mg}$ creatinine, $\mathrm{p}<0.001)$, osmolality (712 mos mol/ $\mathrm{kg}$ vs $573 \mathrm{mos} \mathrm{mol} / \mathrm{kg}, \mathrm{p}=0.006)$, NAG (17.7 U/g creatinine vs $42.9 \mathrm{U} / \mathrm{g}$ creatinine, $\mathrm{P}=0.045)$, and $\beta 2 \mathrm{M}$ ( $0.09 \mathrm{microg} / \mathrm{mg}$ creatinine vs $0.13 \mathrm{microg} / \mathrm{mg}$ creatinine, $\mathrm{P}=0.029)$ [33].

\section{Glomerular dysfunction}

Changes in glomerular function are also evident in multi transfused patients with $\beta$-thalassemia. Chronic anaemia is thought to reduce systemic vascular resistance leading hyperdynamic circulation and subsequent increased renal plasma flow and glomerular filtration rate (GFR) [34]. Glomerular hyperfiltration appears to be deleterious on the mesangial compartment causing it to increase matrix volume and cellularity, initiating a sclerotic process $[35,36]$. In the long-term, such modifications may theoretically lead to a progressive decline in GFR through the typical pathway of hyperfiltration - albuminuria progressive renal damage. Furthermore, renal tubular cells that are subject to iron overload, induce injury into the interstitium by releasing cytokines and growth factors that may cause tubulointerstitial scarring and glomerular sclerosis [37].

As noted earlier, when iron exceeds the binding capacity of transferrin as occurs in iron overload, it accumulates as a nontransferrin-bound iron which accelerates the generation of radical oxygen species and cellular damage.

Additional independent factors that contribute to renal injury may be glomerulonephritis induced by HIV, hepatitis B and hepatitis C infections as well as non-iron related liver and heart disease [38].

Calculation of GFR based on serum creatinine concentration or creatinine clearance demonstrated glomerular hyperfiltration in studies performed in children, adolescents and adults with TDT receiving iron chelation therapy $[10,39,40]$. Noteworthy, Milo et al demonstrated reduced GFR in 9 TDT patients through use of inulin clearance [41]. Individuals were on chelation therapy with DFX for at least 1 year. All patients had lower inulin clearance and GFR than normal healthy young adults, while 4 of 9 patients had mild to moderate chronic kidney disease (CKD). By using Cockcroft-Gault (CG) equation and serum creatinine, median creatinine clearance in the same study was 134.9 (mean 133.3 ) $\mathrm{ml} / \mathrm{min}$ per $1.73 \mathrm{~m} 2$, significantly higher than the GFR estimated by inulin clearance $(\mathrm{P}<0.008)[41]$.

Economou et al, who used cystatin C (Cys C) in 42 pediatric and adult patients with TM, also described a reduction in GFR as compared to normal controls $(\mathrm{p} \leq 0.001)$. Elevated Cys $\mathrm{C}$ levels, but not normal, were also significantly accompanied by other indexes of glomerular dysfunction, such as proteinuria $(223.28 \pm 125.84$ and $79.34 \pm 29.1$ $\mathrm{mg} / \mathrm{m} 2 /$ day, respectively, $\mathrm{p}<0.0001$ ). All patients of the study were 
chronically transfused and under regular chelation program consisted of either DFX or combination of DFP and DFO [42]. In accordance, elevated Cys $\mathrm{C}$ levels were also visualized in TM patients not receiving chelation therapy [43].

Quinn et al applied 24-h urine collection and reported similar levels of creatinine clearance (mean $136.1 \mathrm{ml} / \mathrm{min}$ per $1.73 \mathrm{~m} 2$ ) in 106 adult patients with TM, the majority of whom were treated with DFP or DFO. When they assessed GFR using this method, they predicted hyperfiltration [10]. On the other hand, Piga et al reported normal GFR measured by plasma sampling of 51Cr EDTA in patients with TM [44].

Taken together, the estimations regarding GFR are frequently variable and inconsistent. It is most of the times obvious, that these variations derive from the different parameters applied in each study. Patient demographics, clinical characteristics, comorbidities and iron chelation therapy in addition to the study design and data analysis are important factors that might influence outcome of each study.

Milo et colleagues propose inulin clearance as a more accurate method which may lead to early detection of reduced GFR and slow the progressive deterioration to CKD. Noteworthy, as the authors state, the same study has some limitations such as the fact that involves a relatively small number of participants. Additionally, it is a crosssectional study and all participants were adults (median age was 30 , range 21 to 37 years).

Reduced estimated GFR based on serum creatinine (MDRD study simplified equation) has also been demonstrated in a cohort of TM adult patients regularly followed-up for 10 years. As in the previous study, all patients were transfusion-dependent, treated with iron chelation and adults at the time of the enrolment. Thus, it is unclear whether hyperfiltration preceded demonstrated reduced GFR or has never existed. This theory could be supported by similar studies conducted in children with TM, but to our knowledge current bibliography lacks such data.

Other factors that favor glomerular hyperfiltration are male gender and history of splenectomy according to data derived from univariate and multivariate analysis among adult, multi transfused patients with TM and TI [45].

The variability of GFR estimations might, indeed, by related to the method used for GFR calculation. Equations based on serum creatinine (e.g. CKD-EPI, MDRD) overestimate GFR due to the low serum creatinine levels observed in patients with TM, which might be related to their muscular atrophy and reduced muscle mass and therefore decreased generation. On the contrary, urinary creatinine excretion in healthy people is expected to equal creatinine generation, most of which is generated by muscle metabolism [46-48]. Other possible factors contributing to low serum creatine in thalassemia patients are compensated increased tubular creatinine secretion which prevents its appropriate rise in serum, or extrarenal creatinine metabolism, especially when kidney function is reduced [49,50]. Lastly, variability in serum creatine measurements among individuals may additionally contribute to overestimation of GFR [48].

Calculation of GFR based on creatinine clearance (e.g. CockcroftGault Equation) might also result in overestimation of GFR, which may be encountered as hyperfiltration. In this case, increased creatinine clearance is in large part due to the proximal tubular secretion of creatinine. Urinary creatinine excretion is composed of filtered creatinine and proximal tubular secretion of creatinine. As glomerular disease progresses, the remnant tubular cells hyper secrete creatinine, resulting in increased creatinine excretion and thus elevated creatine clearance [49].

Measurement of the area under the plasma clearance curve (AUC) following a single intravenous injection of 51Cr-EDTA is another procedure for determining GFR. Similarly, to the methods described before, it has been proved that measurement of GFR by 51Cr-EDTA overestimates the true renal clearance by approximately $10 \%$ [51].

Cys $\mathrm{C}$ is a low molecular weight proteinase inhibitor that is produced in all nucleated cells and maintains a constant appearance rate in blood. Opposed to serum creatinine, serum Cys $\mathrm{C}$ concentration is independent of gender and muscle mass [52]. Cys $\mathrm{C}$ is freely filtered through renal glomeruli and then totally reabsorbed and catabolized in the proximal renal tubule and is not returned to blood. Thus, serum concentration is mainly determined by GFR [53]. Previous studies have demonstrated the superiority of serum Cys $\mathrm{C}$ compared to $\mathrm{Cr}$ in the evaluation of GFR, particularly when there is a minor reduction in GFR [54,55]. Inulin clearance is the most widely accepted method for estimating GFR [56]. However, this is a method that, due to its complexity, cannot be routinely used in clinical practice. The use of an accurate method to calculate GFR method may lead to early detection of reduced GFR and slow the progressive deterioration to chronic kidney disease.

\section{Haematuria}

An Iranian study involving a comparative evaluation in 108 children with $\beta$-thalassemia TDT or NTDT demonstrated microscopic haematuria in 19 patients. Interestingly, haematuria was more common in NTDT than TDT (90\% vs. 10\%) [57]. A subsequent study revealed the presence of microscopic haematuria in $10.6 \%$ from a total of 500 patients with TDT, while at the same time its frequency was significantly increased in ages over 20 years old $(9.8 \%$ vs. $20 \%, \mathrm{p}=.04)$ [58]. The presence of haematuria might be related to either hypercalciuria or hyperuricosuria and nephrolithiasis [57].

\section{Nephrolithiasis}

The prevalence of nephrolithiasis in TDT population might reach $59 \%$, as demonstrated in a study involving 27 subjects with TM by non-iodinated contrast renal tract CT. Among affected subjects, $69 \%$ had multiple stones, whereas $56 \%$ of the affected patients had stones of variable composition. The majority of renal calculi were struvite (33\%), followed by calcium oxalate (31\%) and cystine (22\%). Development of struvite stones may warrant an evaluation for an underlying infection [59].

Through a retrospective study of 166 participants with TDT, Wong et al showed that nephrolithiasis is associated with reduced bone mineral density of the femoral neck (odds ratio $(\mathrm{OR})=5.59,95$ $\%$ CI 1.16-27.03) and increased risk of fracture in males $(\mathrm{OR}=2.13)$ [60]. Significantly stone formers in this study had elevated creatinine and lower ferritin serum levels suggesting that DFX is involved as a causative factor [60]. The impact of hypercalciuria after vitamin D and calcium supplementation on renal stone development in the general population remains controversial $[61,62]$. Similarly, calcium or vitamin D supplementation was nor found to be a risk factor for kidney stones in individuals with thalassemia [59]. Among other stone types, hyperuricosuria due to tubular dysfunction and increased cell turnover has been associated with uric acid urolithiasis in the general population. However, in TDT patients, uric acid stones represented only $2 \%$ of all stones which might be reflected by the increased frequency of blood transfusion which limits cell turnover [59]. Splenectomy was proved 
to be an independent risk factor for developing hyperuricemia and nephrolithiasis in patients with TI by further increasing erythrocyte turnover and number. Despite xanthine oxidase inhibition, patients receiving allopurinol had both significantly higher level of serum urate and higher prevalence of urolithiasis as compared to those not receiving $(\mathrm{p}<0.01)$ [63].

\section{The role of iron chelating agents in renal disease}

The advent of iron chelators improved patient survival in $\beta$-thalassemia, however this achievement has allowed previously unrecognized complications to come on the scene. Currently, three iron chelators are available: oral agents deferasirox (DFX), deferiprone (DFP), as well as parenteral deferoxamine mesylate (DFO). Renal manifestations attributed to chelating agents are rare. Although serum ferritin levels have been inversely correlated with GFR, iron chelation therapy has also been related to renal function deterioration $[64,65]$. Oral agent DFP lacks support of large randomized controlled trials. About two decades ago, Hoffbrand et al studied the efficacy and safety of DFP in 51 transfusion dependent iron overloaded patients. They reported that only 1 patient discontinued the drug after 4 months of treatment because of renal failure, however, that patient was not thalassaemic [66]. El Alfy et al from a study of 100 children under 10 years (mean 5.1 years) with TDT (91 patients with TM) and given 50-100 mg/kg DFP demonstrated a modest non-significant and nonprogressive elevation in serum creatinine from a baseline mean of 29.2 \pm 12 to $37.1 \pm 10 \mathrm{micromol} / \mathrm{L}$ over a 6 -month period. Two patients had baseline serum creatinine values of 71 and $62 \mathrm{micromol} / \mathrm{L}$, which resolved by the end of the study, while two others had a single but transient episode of elevation of serum creatinine above the upper limit of normal, which resolved by the end of the study without a need for interruption of therapy or dose adjustment [67]. The etiology for these fluctuations is unclear but have not seen in other currently available data. Although DFP is not considered nephrotoxic, is characterized by a narrow therapeutic window and serious adverse effects, such as agranulocytosis, neutropenia and disabling arthropathy [68]. Thus, is approved specifically for patients with TDT when treatment with other chelating agents is contraindicated or inadequate.

It also binds intracellular iron inducing ferritin degradation through proteasome mediated mechanism [69]. DFX is generally well tolerated. Due to its lipophilicity, DFX enters the tubular cells and forms a highly charged complex with iron. This triple negative charged DFXiron complex less readily penetrates membranes, accumulates and may result in proximal tubulopathy and Fanconi syndrome (FS) [70]. FS is associated with non-anion gap metabolic acidosis, hypophosphatemia due to phosphaturia, aminoaciduria, proteinuria and glucosuria (with normal serum glucose concentrations). Despite its importance, there is limited data about the risk factors, incidence and clinical picture of FS in patients receiving DFX. A retrospective study conducted by Chuang et al indicated younger age of treatment initiation as the sole factor that was significantly associated with FS (7.8 vs. 19.2 years, $\mathrm{p}=$ 0.008) [71]. Similarly, to other reports, patients in this study did not document complete FS. FS generally affects less than $1 \%$ of patients, mainly those treated for more than 6 months [70-83]. Successful management is usual upon discontinuation of DFX and repletion of fluid and electrolyte deficits while efficacy of plasmapheresis has not been confirmed deficits [72,74,75,79,80,81,84-86]. Unfortunately, recurrence even after initiation of lower doses of drug may occur $[74,79]$ (Table 3). Moreover, DFX at therapeutic doses in TM patients was also associated with hypercalciuria providing a biological mechanism for both increased kidney stones and accelerated bone resorption $[87,88]$. Dose-dependent increases in serum creatinine were observed in $38 \%$ of TDT patients treated with $20-30 \mathrm{mg} / \mathrm{kg}$ DFX. However, these increases

Table 3. Deferasirox induced Fanconi syndrome

\begin{tabular}{|c|c|c|c|c|c|c|}
\hline Authors & Study design & Patient population & $\begin{array}{l}\text { Comorbidities/ } \\
\text { other potentially } \\
\text { nephrotoxic } \\
\text { medications }\end{array}$ & $\begin{array}{l}\text { Dose and } \\
\text { duration of } \\
\text { treatment }\end{array}$ & Clinical picture & Outcome \\
\hline $\begin{array}{l}{ }^{99} \text { Chuang et al, } \\
2015\end{array}$ & $\begin{array}{l}\text { Cohort study, } \\
\text { single centre, } \\
\text { evaluating the } \\
\text { incidence of } \\
\text { DFX-related } \\
\text { FS and its risk } \\
\text { factors. }\end{array}$ & $\begin{array}{l}57 \text { patients with } \\
\text { TDT, aged } 7.8 \pm 4.4 \\
\text { years old }\end{array}$ & None & $\begin{array}{l}9299 \pm 1774 \\
\mathrm{mg} / \mathrm{kg} / \text { year } \\
\text { for } 6.9 \pm 1.8 \\
\text { years }\end{array}$ & $\begin{array}{l}\text { Non-anion gap metabolic acidosis, } \\
\text { hypophosphatemia, glucosuria }\end{array}$ & $\begin{array}{l}\text { DFX was stopped. All features of } \\
\text { proximal tubular dysfunction resolved. }\end{array}$ \\
\hline${ }^{106}$ Rafat et al, 2009 & Case report & $\begin{array}{l}\text { 78-year-old male } \\
\text { with sideroblastic } \\
\text { anaemia }\end{array}$ & $\begin{array}{l}\text { DM, CLL, aortic } \\
\text { valve replacement, } \\
\text { and essential } \\
\text { hypertension/ } \\
\text { perindopril, } \\
\text { glibenclamide, } \\
\text { metformin }\end{array}$ & $\begin{array}{l}24 \mathrm{mg} / \mathrm{kg} / \mathrm{d} \text { for } \\
1 \text { month }\end{array}$ & $\begin{array}{l}\text { Non-anion gap metabolic acidosis, } \\
\text { hypophosphatemia, glycosuria, proteinuria, } \\
\text { hypourichemia, increased } \beta 2 \text {-microglobulin } \\
\text { urinary level. Increase in serum creatinine } \\
\text { from } 0.9 \text { to } 2 \mathrm{mg} / \mathrm{dl} \text {. }\end{array}$ & $\begin{array}{l}\text { DFX was stopped. Resolution of } \\
\text { tubulopathy apart from minimal } \\
\text { proteinuria. Serum creatinine } 1.2 \mathrm{mg} / \mathrm{dl}\end{array}$ \\
\hline $\begin{array}{l}{ }_{204}^{104} \text { Murphy et al, } \\
2013\end{array}$ & Case report & $\begin{array}{l}\text { 21-year-old male } \\
\text { with Ewing sarcoma }\end{array}$ & Ifosfamide & $\begin{array}{l}1125 \mathrm{mg} / \mathrm{d} \text { for } \\
9 \text { months }\end{array}$ & $\begin{array}{l}\text { Hypophosphatemia, hypokalaemia, } \\
\text { glycosuria, proteinuria, kaliuresis. } \\
\text { Increase in serum creatinine from } 1.1 \text { to } \\
2.5 \mathrm{mg} / \mathrm{dl} \text {. Kidney biopsy revealed severe } \\
\text { tubular injury } \\
\text { with tubular epithelial cells demonstrating } \\
\text { isometric vacuolization consistent with } \\
\text { drug toxicity }\end{array}$ & $\begin{array}{l}\text { DFX was stopped. Fluid and electrolyte } \\
\text { supplementation. SCr fell to } 1.5 \mathrm{mg} / \\
\text { dL and } \\
\text { bicarbonate normalized. Persistent } \\
\text { hypokalemia, hypophosphatemia, } \\
\text { proteinuria, } \\
\text { and glycosuria }\end{array}$ \\
\hline${ }^{114}$ Shah et al, 2017 & Case report & $\begin{array}{l}\text { 20-year-old male } \\
\text { with TDT admitted } \\
\text { for a scheduled } \\
\text { allogenic stem cell } \\
\text { transplant }\end{array}$ & Fludarabine & $\begin{array}{l}20-30 \mathrm{mg} / \\
\mathrm{kg} / \mathrm{d} \text { for } 8 \\
\text { years. Due to } \\
\text { dispensing } \\
\text { error he } \\
\text { received a } \\
\text { one-time dose } \\
\text { of } 90 \mathrm{mg} / \mathrm{kg} \text {. }\end{array}$ & $\begin{array}{l}\text { Acute onset, following high dose } \\
\text { administration. Metabolic acidosis, } \\
\text { glycosuria, haematuria, phosphaturia, } \\
\text { kaliuresis and elevated } \beta 2- \\
\text { microglobulinuria }\end{array}$ & $\begin{array}{l}\text { DFX was stopped. } \\
\text { Fluid and electrolyte supplementation. } \\
\text { Plasmapheresis. All features of } \\
\text { proximal tubular dysfunction resolved. }\end{array}$ \\
\hline
\end{tabular}




\begin{tabular}{|c|c|c|c|c|c|c|}
\hline \multirow[t]{2}{*}{$\begin{array}{l}{ }^{12} \text { Papneja et al, } \\
2016\end{array}$} & \multirow[t]{2}{*}{$\begin{array}{l}\text { Two Case } \\
\text { reports, } \\
\text { two centres }\end{array}$} & $\begin{array}{l}\text { 16-year-old male } \\
\text { with DBA }\end{array}$ & None & $\begin{array}{l}30 \mathrm{mg} / \\
\mathrm{kg} / \mathrm{d} \text { for } 6 \\
\text { years with } \\
\text { a transient } \\
\text { increase to a } \\
\text { maximum } \\
\text { of } 45 \mathrm{mg} / \mathrm{kg} / \\
\text { day during the } \\
\text { last year. }\end{array}$ & $\begin{array}{l}\text { Non-anion gap metabolic acidosis } \\
\text { hypokalaemia, hypophosphatemia, } \\
\text { phosphaturia, } \\
\text { glucosuria, and proteinuria }\end{array}$ & $\begin{array}{l}\text { DFX was stopped. Fluid and electrolyte } \\
\text { supplementation. FS was resolved. DFX } \\
\text { was restarted. }\end{array}$ \\
\hline & & $\begin{array}{l}\text { 14-year-old male } \\
\text { with DBA }\end{array}$ & None & $\begin{array}{l}36 \\
\mathrm{mg} / \mathrm{kg} / \mathrm{d} \text { for } \\
10 \text { months }\end{array}$ & $\begin{array}{l}\text { Non-anion gap metabolic acidosis } \\
\text { hypokalaemia, hypophosphatemia, } \\
\text { hyper phosphaturia, glucosuria, and } \\
\text { proteinuria. Increase in } \mathrm{SCr} \text { from } 59 \mu \mathrm{mol} / 1 \\
\text { to } 204 \mu \mathrm{mol} / 1 \text {. }\end{array}$ & $\begin{array}{l}\text { DFX was stopped. Fluid and electrolyte } \\
\text { supplementation. SCr was normalized. } \\
\text { All features of proximal tubular } \\
\text { dysfunction resolved. DFX was } \\
\text { restarted. }\end{array}$ \\
\hline${ }^{100}$ Dee et al, 2014 & $\begin{array}{l}\text { Cohort study, } \\
\text { single centre, } \\
\text { evaluating the } \\
\text { incidence of } \\
\text { DFX-related } \\
\text { FS. }\end{array}$ & $\begin{array}{l}9 \text { patients with TDT, } \\
\text { aged } 2.6 \text { to } 23.8 \\
\text { years old }\end{array}$ & $\begin{array}{l}\text { One patient had } \\
\text { influenza virus H3N2 } \\
\text { and developed severe } \\
\text { hypokalaemia while } \\
\text { on DFX. } \\
\text { Another patient had } \\
\text { Echovirus type } 6 \\
\text { infection } 10 \text { months } \\
\text { before the onset } \\
\text { of renal tubular } \\
\text { dysfunction }\end{array}$ & $\begin{array}{l}\text { Dose was not } \\
\text { indicated. } \\
\text { Cumulative } \\
\text { incidence was } \\
\text { estimated } \\
\text { at } 11 \% \text { at } 2 \\
\text { months and } \\
\text { about } 90 \% \\
\text { at } 6 \text { years of } \\
\text { DFX therapy }\end{array}$ & $\begin{array}{l}\text { Metabolic acidosis }(33 \%) \text {, elevated urine } \\
\beta 2 \mathrm{M} \text { [Odds ratio }(\mathrm{OR})=35.29, \mathrm{P}=0.0009] \\
\text { hypokalaemia }(\mathrm{OR}=23.22, \mathrm{P}=0.015) \\
\text { hypophosphatemia }(\mathrm{OR}=57.00, \mathrm{P}=0.001) \\
\text { hypocalcaemia }(\mathrm{OR}=23.22, \mathrm{P}=0.015)\end{array}$ & $\begin{array}{l}\text { Normalized after reduction or } \\
\text { withdrawal of DFX. }\end{array}$ \\
\hline${ }^{113}$ Tunc et al, 2012 & $\begin{array}{l}\text { Cohort study, } \\
\text { single centre, } \\
\text { evaluating the } \\
\text { incidence of } \\
\text { DFX-related } \\
\text { adverse events. }\end{array}$ & $\begin{array}{l}8 \text { patients with } \\
\text { Fanconi anaemia } \\
\text { aged } 12.8 \pm 3.6 \text { years } \\
\text { old }\end{array}$ & $\begin{array}{l}\text { All patients } \\
\text { were receiving } \\
\text { oxymetholone. }\end{array}$ & $\begin{array}{l}10-30 \mathrm{mg} / \\
\mathrm{kg} / \mathrm{d} \text { for } 13.6 \pm \\
5.8 \text { months }\end{array}$ & $\begin{array}{l}\text { Proteinuria }(87.5 \%) \text {. Increase in } \mathrm{SCr} \\
(37.5 \%) \text { in: a patient with unilateral renal } \\
\text { agenesis (from } 1.03 \mathrm{mg} / \mathrm{dL} \text { to } 1.44 \mathrm{mg} / \\
\mathrm{dL}) \text {, a patient who undergone surgery } \\
\text { for cellulitis ( } \mathrm{SCr} 1.28 \mathrm{mg} / \mathrm{dL} \text { ), a patient } \\
\text { with congenital abnormality of the right } \\
\text { duplicated collecting system during sepsis } \\
(\mathrm{SCr} 1.26 \mathrm{mg} / \mathrm{dL})\end{array}$ & $\begin{array}{l}\text { SCr was normalized in } 2 / 3 \text { of patients } \\
\text { after transient cessation of DFX. Other } \\
\text { information is not provided. }\end{array}$ \\
\hline \multirow[t]{2}{*}{$\begin{array}{l}{ }^{107} \text { Rheault et al, } \\
2011\end{array}$} & \multirow[t]{2}{*}{$\begin{array}{l}\text { Two case } \\
\text { reports }\end{array}$} & $\begin{array}{l}\text { 7.5-year-old-male } \\
\text { with TDT }\end{array}$ & None & $\begin{array}{l}30 \mathrm{mg} / \mathrm{kg} / \mathrm{d} \\
\text { for } 18 \text { months. }\end{array}$ & $\begin{array}{l}\text { Normal-anion gap metabolic acidosis, } \\
\text { hypokalaemia, phosphaturia, glucosuria, } \\
\text { aminoaciduria } \\
\text { hypercalciuria. }\end{array}$ & $\begin{array}{l}\text { DFX was stopped. Fluid and electrolyte } \\
\text { supplementation. Features FS were } \\
\text { improved. DFX was restarted at } 20 \mathrm{mg} / \\
\mathrm{kg} / \mathrm{d} \text { with evidence of mild FS (elevated } \\
\text { urine } \beta 2 \mathrm{M} \text {, hypercalciuria). }\end{array}$ \\
\hline & & $\begin{array}{l}\text { 8.5-year-old-female } \\
\text { with TDT }\end{array}$ & None & $\begin{array}{l}30 \mathrm{mg} / \mathrm{kg} / \mathrm{day} \\
\text { for } 12 \mathrm{months} \text {. }\end{array}$ & $\begin{array}{l}\text { Elevated protein to creatinine ratio }(0.38) \text {, } \\
\text { urine calcium to creatinine ratio }(0.46) \text { and } \\
\text { urine } \beta 2 \mathrm{M} \text {. }\end{array}$ & Stable without intervention. \\
\hline${ }^{108}$ Wei et al, 2011 & Case report & $\begin{array}{l}\text { 18.75-year-old male } \\
\text { with TDT }\end{array}$ & $\begin{array}{l}\text { Secondary } \\
\text { hypothyroidism and } \\
\text { hypogonadotropic } \\
\text { hypogonadism/ } \\
\text { oral thyroxine, } \\
\text { intramuscular } \\
\text { testosterone } \\
\text { cypionate }\end{array}$ & $\begin{array}{l}28.9-35.3 \mathrm{mg} / \\
\mathrm{kg} / \mathrm{d} \text { for } 27 \\
\text { months. }\end{array}$ & $\begin{array}{l}\text { Proteinuria, glycosuria, hypophosphatemia, } \\
\text { hypocalcaemia, hyponatremia, } \\
\text { hypokalaemia, } \\
\text { metabolic acidosis, low serum uric acid, } \\
\text { elevated urinary } \\
\beta 2 \mathrm{M} \text {. Increase in SCr from } 0.5 \text { to } 1.74 \\
\mathrm{mg} / \mathrm{dL} \text {. Also developed coma, hepatic } \\
\text { dysfunction and thrombocytopenia. }\end{array}$ & $\begin{array}{l}\text { Fluid and electrolyte supplementation. } \\
\text { DFX was stopped and patient had full } \\
\text { recovery. }\end{array}$ \\
\hline \multirow{4}{*}{$\begin{array}{l}{ }^{109} \text { Yacobovich et } \\
\text { al, } 2010\end{array}$} & \multirow{4}{*}{$\begin{array}{l}\text { Four case } \\
\text { reports }\end{array}$} & $\begin{array}{l}8.5 \text {-year-old female } \\
\text { with TDT }\end{array}$ & None & $\begin{array}{l}30 \mathrm{mg} / \mathrm{kg} / \mathrm{d} \\
\text { for } 8 \text { months. }\end{array}$ & $\begin{array}{l}\text { Metabolic acidosis, glycosuria, } \\
\text { hypokalaemia, hypophosphatemia. }\end{array}$ & $\begin{array}{l}\text { DFX was stopped. Fluid and electrolyte } \\
\text { supplementation. FS was resolved. }\end{array}$ \\
\hline & & $\begin{array}{l}\text { 11-year-old female } \\
\text { with TDT }\end{array}$ & None & $\begin{array}{l}30 \mathrm{mg} / \mathrm{kg} / \mathrm{d} \\
\text { for } 24 \text { months. }\end{array}$ & $\begin{array}{l}\text { Metabolic acidosis, glycosuria, low serum } \\
\text { uric acid, hypokalaemia, } \\
\text { hypophosphatemia } \\
\text { and elevated urine lysozyme. Also had } \\
\text { gastroenteritis. }\end{array}$ & $\begin{array}{l}\text { DFX was stopped. Fluid and electrolyte } \\
\text { supplementation. FS was resolved. }\end{array}$ \\
\hline & & $\begin{array}{l}\text { 8-year-old male with } \\
\text { TDT }\end{array}$ & None & $\begin{array}{l}30 \mathrm{mg} / \mathrm{kg} / \mathrm{d} \\
\text { for } 36 \text { months. }\end{array}$ & $\begin{array}{l}\text { Metabolic acidosis, glycosuria, low serum } \\
\text { uric acid, hypokalaemia, } \\
\text { hypophosphatemia } \\
\text { and elevated urine lysozyme. Also had } \\
\text { gastroenteritis. }\end{array}$ & $\begin{array}{l}\text { DFX was stopped. Fluid and electrolyte } \\
\text { supplementation. FS was resolved. }\end{array}$ \\
\hline & & $\begin{array}{l}\text { 32-year-old female } \\
\text { with TDT }\end{array}$ & $\begin{array}{l}\text { Calcium plus vitamin } \\
\text { D supplement. Also, } \\
\text { on ofloxacin and } \\
\text { phenazopyridine } \\
\text { HCL for a recently } \\
\text { diagnosed urinary } \\
\text { tract infection }\end{array}$ & $\begin{array}{l}38 \mathrm{mg} / \mathrm{kg} / \mathrm{d} \\
\text { for } 33 \text { months. }\end{array}$ & $\begin{array}{l}\text { Metabolic acidosis, glycosuria, low } \\
\text { serum uric acid, hypokalaemia, } \\
\text { hypophosphatemia, kaliurisis. }\end{array}$ & $\begin{array}{l}\text { DFX was stopped. Fluid and electrolyte } \\
\text { supplementation. FS was resolved. }\end{array}$ \\
\hline $\begin{array}{l}{ }^{103} \text { Grange et al, } \\
2010\end{array}$ & Case report. & $\begin{array}{l}\text { 77-year-old male } \\
\text { with non- hereditary } \\
\text { hemochromatosis. }\end{array}$ & $\begin{array}{l}\text { Hypertension/ } \\
\text { irbesartan, HCTZ, } \\
\text { ursodesoxycholic } \\
\text { acid }\end{array}$ & $\begin{array}{l}1500 \mathrm{mg} / \mathrm{day} \\
\text { for } 1 \mathrm{month} .\end{array}$ & $\begin{array}{l}\text { Glycosuria, hypokalaemia, } \\
\text { hypophosphatemia, hypocalcaemia, } \\
\text { kaliurisis, phosphaturia, aminoaciduria. } \\
\text { Increase in SCr at } 180 \mu \mathrm{mol} / \mathrm{L} \text {. }\end{array}$ & $\begin{array}{l}\text { DFX was stopped. Fluid and electrolyte } \\
\text { supplementation. FS was resolved. SCr } \\
\text { was normalized. }\end{array}$ \\
\hline
\end{tabular}




\begin{tabular}{|c|c|c|c|c|c|c|}
\hline \multirow[t]{2}{*}{$\begin{array}{l}{ }^{102} \text { Even-Or et al, } \\
2009\end{array}$} & \multirow[t]{2}{*}{$\begin{array}{l}\text { Two case } \\
\text { reports. }\end{array}$} & $\begin{array}{l}18 \text {-year-old male } \\
\text { with pure red cell } \\
\text { aplasia. }\end{array}$ & None. & $\begin{array}{l}20 \mathrm{mg} / \mathrm{kg} / \mathrm{d} \\
\text { for } 6 \text { months. }\end{array}$ & $\begin{array}{l}\text { Glycosuria, uricosuria, phosphaturia, } \\
\text { kaliuria, aminoaciduria, low serum uric } \\
\text { acid, hypokalaemia, hypophosphatemia. } \\
\text { Increase in } \mathrm{SCr} \text { from } 0.6 \text { to } 1.07 \mathrm{mg} / \mathrm{dL} \text {. }\end{array}$ & $\begin{array}{l}\text { DFX was stopped. FS and } \mathrm{SCr} \text { were } \\
\text { resolved. DFX was restarted and mild } \\
\text { hypouricemia, hypophosphatemia, } \\
\text { phosphaturia and increased urinary } \beta 2 \mathrm{M} \\
\text { within a few weeks, while on } 10 \mathrm{mg} / \\
\mathrm{kg} / \text { day of DFX. He continued treatment } \\
\text { with increasing doses with no further } \\
\text { deterioration. }\end{array}$ \\
\hline & & $\begin{array}{l}\text { 11-year-old female } \\
\text { with }\end{array}$ & Acute graft & $30 \mathrm{mg} / \mathrm{kg} / \mathrm{d}$ & Glycosuria, uricosuria, & $\begin{array}{l}\text { DFX was stopped. Electrolyte } \\
\text { supplementation. FS was resolved. }\end{array}$ \\
\hline
\end{tabular}

DFX: Deferasirox; FS: Fanconi syndrome; Scr: Serum creatinine; DBA: Diamond-Blackfan anemia, $\beta 2 \mathrm{M}$ : $\beta 2$ micro globulin; HCTZ: Hydrochlorothiazide; AHSCT: Allogeneic hematopoietic stem cell transplantation

were sometimes transient, never exceeded two times the upper limit of normal (ULN) and generally within the normal range [82]. Later studies in adult and paediatric patients with TDT and normal renal function, confirmed absence of progressive increases in serum creatinine over a 5-year follow up after treatment. Consecutive serum creatinine level increases $>33 \%$ above the value at the start of DFX and greater than the ULN were reported $8.8 \%$ patients, mostly in doses 25 to $35 \mathrm{mg} / \mathrm{kg} /$ day. Nonetheless, these increases were manageable and did not lead to drug interruption [83]. Furthermore, DFX proved to be safe in managing iron overload in thalassemia patients with end stage renal disease or diabetes mellitus $[89,90]$.

DFO chelates iron located in plasma and ferritin by forming a metabolically inactive complex, that is renally excreted. DFO is poorly absorbed by the oral route. Consequently, intravenous or subcutaneous administration is required [91]. Acute renal failure necessitating dialysis following intravenous DFO overdose was described in patients who received 10-times the recommended dose due to administration pump failure or with inadequate monitoring $[65,92]$. Similarly, to DFX, transient and within the normal range serum creatinine increases have been documented in $14 \%$ of patients receiving DFO, whereas the same agent was also associated with increased level of NAG and tubular dysfunction in patients with TM $[82,93]$. Of importance, DFO poses a risk of Yersinia, Mucor mycosis (zygomycosis) and Vibrio vulnificus infection and sepsis, an additional causative factor of acute kidney injury if left untreated [94-96]

The mechanisms involved in GFR alteration concurrently with iron depletion include impaired mitochondrial function and consequent production of adenosine and adenosine triphosphate that lead to activation of the tubulo-glomerular feedback and vasoconstriction of the afferent glomerular arterioles. Interference with prostaglandin production and imbalance between vasodilating and vasoconstrictive substances is also implicated in GFR reduction [65].

The management of serum creatinine elevation should be individualized based on the magnitude of increase and the presence for additional risk factors for renal disease or comorbid conditions. Recommendations for dose modifications and monitoring in patients who experience DFX-associated adverse events are available [97].

\section{Conclusion}

In conclusion, more longitudinal data are required to fully portray any possible differences in renal disease in TDT and NTDT patients, as well the current prevalence of this comorbidity in the era of new iron chelation and blood transfusion guidelines. There is a need for close monitoring and follow-up of renal function both in NTDT and TDT patients as their life expectancy has increased, and this puts them potentially at increased risk of severe renal disease.

\section{Disclosure of interest}

The authors report no conflict of interest

\section{References}

1. Yesilipek MA (2007) Stem cell transplantation in hemoglobinopathies. Hemoglobin 31: 251-256. [Crossref]

2. Rivella $S$ (2015) $\hat{\mathrm{I}}^{2}$-thalassemias: paradigmatic diseases for scientific discoveries and development of innovative therapies. Haematologica 100: 418-430. [Crossref]

3. Shinar E1, Rachmilewitz EA (1990) Oxidative denaturation of red blood cells in thalassemia. Semin Hematol 27: 70-82. [Crossref]

4. Yuan J, Kannan R, Shinar E, Rachmilewitz EA, Low PS (1992) Isolation, characterization, and immunoprecipitation studies of immune complexes from membranes of beta-thalassemic erythrocytes. Blood 79: 3007-3013. [Crossref]

5. Origa R (2017) Beta-Thalassemia. Genetics in medicine: Official journal of the American College of Medical Genetics Gene Reviews 19: 609-619. [Crossref]

6. DeLoughery TG (2014) Microcytic anemia. N Engl J Med 371: 2537. [Crossref]

7. Weatherall DJ1 (2010) The inherited diseases of hemoglobin are an emerging global health burden. Blood 115: 4331-4336. [Crossref]

8. Modell B, Darlison M (2008) Global epidemiology of haemoglobin disorders and derived service indicators. Bulletin of the World Health Organization 86:480-487. [Crossref]

9. Ginzburg Y, Rivella S (2011) $\hat{I}^{2}$-thalassemia: a model for elucidating the dynamic regulation of ineffective erythropoiesis and iron metabolism. Blood 118: 4321-4330. [Crossref]

10. Quinn CT, Johnson VL, Kim HY, Trachtenberg F, Vogiatzi MGet al. (2011) Rena dysfunction in patients with thalassaemia. Br J Haematol 153:111-7. [Crossref]

11. Yaghobi M, Miri-Moghaddam E, Majid N, Bazi A, Navidian A, et al. (2017) Complications of Transfusion-Dependent Beta-Thalassemia Patients in Sistan and Baluchistan, South-East of Iran. Int J Hematol Oncol Stem Cell Res 11: 268-272. [Crossref]

12. Mokhtar GM, Gadallah M, El Sherif NH, Ali HT (2013) Morbidities and mortality in transfusion-dependent Beta-thalassemia patients (single-center experience). Pediatr Hematol Oncol 30: 93-103. [Crossref]

13. Ong-ajyooth L, Malasit P, Ong-ajyooth S, Fucharoen S, Pootrakul P, et al. (1998) Renal function in adult beta-thalassemia/Hb E disease. Nephron 78: 156-161. [Crossref]

14. Ahmadzadeh A, Jalali A, Assar S, Khalilian H, Zandian K, et al. (2011) Renal tubular dysfunction in pediatric patients with beta-thalassemia major. Saudi J Kidney Dis Transpl 22: 497-500. [Crossref]

15. Sadeghi-Bojd S, Hashemi M, Karimi M (2008) Renal tubular function in patients with beta-thalassaemia major in Zahedan, southeast Iran. Singapore Med J 49: 410-412. [Crossref]

16. Sen V, Ece A, Uluca U, Soker M, Gunes A, et al. (2015) Urinary early kidney injury molecules in children with beta-thalassemia major. Renal failure 37: 607-13. [Crossref]

17. Patsaoura A, Tatsi E, Margeli A, Kanavaki I, Delaporta P, et al. (2014) Plasma neutrophil gelatinase-associated lipocalin levels are markedly increased in patients with nontransfusion-dependent thalassemia: Lack of association with markers of erythropoiesis, iron metabolism and renal function. Clin Biochem 47: 1060-1064. [Crossref]

18. Roudkenar MH, Halabian R, Oodi A, Roushandeh AM, Yaghmai P, et al. (2008) Upregulation of neutrophil gelatinase-associated lipocalin, NGAL/Lcn2, in betathalassemia patients. Arch Med Res 39: 402-407. [Crossref] 
19. Aldudak B, Karabay Bayazit A, Noyan A, Ozel A, Anarat A, et al. (2000) Renal function in pediatric patients with beta-thalassemia major. Pediatr Nephrol 15:109112. [Crossref]

20. Mohkam M, Shamsian BS, Gharib A, Nariman S, Arzanian MT (2008) Early markers of renal dysfunction in patients with beta-thalassemia major. Pediatr Nephrol 23:971976. [Crossref]

21. Smolkin V, Halevy R, Levin C, Mines M, Sakran W, et al. (2008) Renal function in children with beta-thalassemia major and thalassemia intermedia. Pediatr Nephrol 23: 1847-1851. [Crossref]

22. Sumboonnanonda A, Malasit P, Tanphaichitr VS, Ong-ajyooth S, Sunthornchart S, et al. (1998) Renal tubular function in beta-thalassemia. Pediatr Nephrol 12: 280-283. [Crossref]

23. Zhou XJ, Laszik Z, Wang XQ, Silva FG, Vaziri ND (2000) Association of renal injury with increased oxygen free radical activity and altered nitric oxide metabolism in chronic experimental hemosiderosis. Lab Invest 80: 1905-1914. [Crossref]

24. Michelakakis H, Dimitriou E, Georgakis H, Karabatsos F, Fragodimitri C, et al. (1997) Iron overload and urinary lysosomal enzyme levels in beta-thalassaemia major. Eur $J$ Pediatr 156: 602-604. [Crossref]

25. Koliakos G, Papachristou F, Koussi A, Perifanis V, Tsatra I, et al. (2003) Urine biochemical markers of early renal dysfunction are associated with iron overload in beta-thalassaemia. Clin Lab Haematol 25: 105-109. [Crossref]

26. Nangaku M (2006) Chronic hypoxia and tubulointerstitial injury: a final common pathway to end-stage renal failure. J Am Soc Nephrol 17: 17-25. [Crossref]

27. Nagababu E, Gulyani S, Earley CJ, Cutler RG, Mattson MP, et al. (2008) Irondeficiency anaemia enhances red blood cell oxidative stress. Free Radic Res 42: 824 829. [Crossref]

28. Manotham K, Tanaka T, Matsumoto M, Ohse T, Inagi R, et al. (2004) Transdifferentiation of cultured tubular cells induced by hypoxia. Kidney Int 65: 871-880. [Crossref]

29. Norman JT, Clark IM, Garcia PL (2000) Hypoxia promotes fibrogenesis in human renal fibroblasts. Kidney Int 58: 2351-2366. [Crossref]

30. Norman JT, Orphanides C, Garcia P, Fine LG (1999) Hypoxia-induced changes in extracellular matrix metabolism in renal cells. Experimental nephrology 7: 463-469.

31. Hashemieh M, Azarkeivan A, Akhlaghpoor S, Shirkavand A, Sheibani K (2012) T2 star $(\mathrm{T} 2 *)$ magnetic resonance imaging for assessment of kidney iron overload in thalassemic patients. Archives of Iranian medicine 15:91-94.

32. Tantawy AA, El Bablawy N, Adly AA, Ebeid FS (2014) Early Predictors of Rena Dysfunction in Egyptian Patients with beta-Thalassemia Major and Intermedia. Mediterranean journal of hematology and infectious diseases 6: e2014057.

33. Sumboonnanonda A, Sanpakit K, Piyaphanee N (2009) Renal tubule function in betathalassemia after hematopoietic stem cell transplantation. Pediatric nephrology. 24 183-187.

34. Davis LE, Hohimer AR (1991) Hemodynamics and organ blood flow in fetal sheep subjected to chronic anemia. Am J Physiol 261: R1542-1548. [Crossref]

35. Lafferty HM, Anderson S, Brenner BM (1991) Anemia: a potent modulator of rena hemodynamics in models of progressive renal disease. American journal of kidney diseases: the official journal of the National Kidney Foundation 17:2-7.

36. Hostetter TH (2003) Hyperfiltration and glomerulosclerosis. Semin Nephrol 23: 194 199. [Crossref]

37. Alfrey AC (1994) Role of iron and oxygen radicals in the progression of chronic rena failure. Am J Kidney Dis 23: 183-187. [Crossref]

38. Musallam KM, Taher AT (2012) Mechanisms of renal disease in $\hat{\mathrm{I}}^{2}$-thalassemia. $J A m$ Soc Nephrol 23: 1299-1302. [Crossref]

39. Schwartz GJ, Brion LP, Spitzer A (1987) The use of plasma creatinine concentration for estimating glomerular filtration rate in infants, children, and adolescents. Pediatr Clin North Am 34: 571-590. [Crossref]

40. Levey AS, Coresh J, Greene T, Stevens LA, Zhang YL, et al. (2006) Using standardized serum creatinine values in the modification of diet in renal disease study equation for estimating glomerular filtration rate. Ann Intern Med 145: 247-54. [Crossref]

41. Milo G, Feige Gross Nevo R, Pazgal I, Gafter-Gvili A, Shpilberg O, et al. (2015) GFR in Patients with beta-Thalassemia Major. Clinical journal of the American Society of Nephrology 10:1350-6.

42. Economou M, Printza N, Teli A, Tzimouli V, Tsatra I, et al. (2010) Renal dysfunction in patients with beta-thalassemia major receiving iron chelation therapy either with deferoxamine and deferiprone or with deferasirox. Acta Haematol 123: 148-152. [Crossref]
43. Hamed EA, ElMelegy NT (2010) Renal functions in pediatric patients with betathalassemia major: relation to chelation therapy: original prospective study. Italian journal of pediatrics $36: 39$.

44. Piga A, Fracchia S, Lai ME, Cappellini MD, Hirschberg Ret al. (2015) Deferasirox effect on renal haemodynamic parameters in patients with transfusion-dependent beta thalassaemia. British journal of haematology 168: 882-890.

45. Deveci B, Kurtoglu A, Kurtoglu E, Salim O, Toptas T (2016) Documentation of renal glomerular and tubular impairment and glomerular hyperfiltration in multitransfused patients with beta thalassemia. Ann Hematol 95: 375-381. [Crossref]

46. Shapira Y, Glick B, Finsterbush A, Goldfarb A, Rosenmann E (1990) Myopathological findings in thalassemia major. European neurology 30: 324-327.

47. Logothetis J, Constantoulakis M, Economidou J, Stefanis C, Hakas P, et al. (1972 Thalassemia major (homozygous beta-thalassemia). A survey of 138 cases with emphasis on neurologic and muscular aspects. Neurology 22: 294-304. [Crossref]

48. Levey AS (1990) Measurement of renal function in chronic renal disease. Kidney Int 38: 167-184. [Crossref]

49. Shemesh O, Golbetz H, Kriss JP, Myers BD (1985) Limitations of creatinine as a filtration marker in glomerulopathic patients. Kidney international 28: 830-838.

50. Hankins DA, Babb AL, Uvelli DA, Scribner BH (1981) Creatinine degradation I: the kinetics of creatinine removal in patients with chronic kidney disease. Intl J Art Org 4: 35-39.

51. Moore AE, Park-Holohan SJ, Blake GM, Fogelman I (2003) Conventiona measurements of GFR using 51Cr-EDTA overestimate true renal clearance by 10 percent. Eur J Nucl Med 30:4-8

52. Filler G, Huang SH, Yasin A (2012) The usefulness of cystatin C and related formulae in pediatrics. Clin Chem Lab Med 50: 2081-2091.

53. Dharnidharka VR, Kwon C, Stevens G (2002) Serum cystatin C is superior to serum creatinine as a marker of kidney function: a meta-analysis. Am J Kidney Dis 40: 221226.

54. Stevens LA, Coresh J, Schmid CH, Feldman HI, Froissart M, et al. (2008) Estimating GFR using serum cystatin $\mathrm{C}$ alone and in combination with serum creatinine: a pooled analysis of 3,418 individuals with CKD. Am J Kidney Dis 51: 395-406.

55. Rigalleau V, Beauvieux MC, Lasseur C, Chauveau P, Raffaitin C, et al. (2007) The combination of cystatin $\mathrm{C}$ and serum creatinine improves the monitoring of kidney function in patients with diabetes and chronic kidney disease. Clin Chem 53: 19881989. [Crossref]

56. Skorecki K, Chertow GM, Marsden PA, Taal MW, Yu ASL (2016) Brenner \& Rector's the kidney.

57. Ali D, Mehran K, Moghaddam AG (2008) Comparative evaluation of renal findings in Beta-thalassemia major and intermedia. Saudi journal of kidney diseases and transplantation 19: 206-209.

58. Fallahzadeh $\mathrm{MH}$, Fallahzadeh MK, Shahriari M, Rastegar S, Derakhshan A, et al. (2010) Hematuria in patients with Beta-thalassemia major. Iran J Kidney Dis 4: 133 136. [Crossref]

59. Wong P, Milat F, Fuller PJ, Kerr PG, Doery JCG, et al. (2017) Urolithiasis is prevalen and associated with reduced bone mineral density in beta-thalassaemia major. Internal medicine journal 47: 1064-1067.

60. Wong P, Fuller PJ, Gillespie MT, Kartsogiannis V, Strauss BJ, et al. (2013) Thalassemia bone disease: the association between nephrolithiasis, bone mineral density and fractures. Osteoporos Int 24: 1965-1971.

61. Heaney RP (2008) Calcium supplementation and incident kidney stone risk: systematic review. J Am Coll Nutr 27: 519-527.

62. Malihi Z, Wu Z, Stewart AW, Lawes CM, Scragg R (2016) Hypercalcemia, hypercalciuria, and kidney stones in long-term studies of vitamin $\mathrm{D}$ supplementation: a systematic review and meta-analysis. The American journal of clinical nutrition 04 1039-1051.

63. Ricchi P, Ammirabile M, Costantini S, Di Matola T, Spasiano A, et al. (2012) Splenectomy is a risk factor for developing hyperuricemia and nephrolithiasis in patients with thalassemia intermedia: a retrospective study. Blood Cells Mol Dis 49: 133-135.

64. Papassotiriou I, Margeli A, Hantzi E, Delaporta P, Sergounioti A, et al. (2010) Cystatin $\mathrm{C}$ levels in patients with beta-thalassemia during deferasirox treatment. Blood Cells Mol Dis 44: 152-155. 
65. Ponticelli C, Musallam KM, Cianciulli P, Cappellini MD (2010) Renal complications in transfusion-dependent beta thalassaemia. Blood Rev 24: 239-244. [Crossref]

66. Hoffbrand AV, F AL-R, Davis B, Siritanakatkul N, Jackson BF, et al. (1998) Long-term trial of deferiprone in 51 transfusion-dependent iron overloaded patients. Blood 91 : 295-300.

67. ElAlfy MS, Sari TT, Lee CL, Tricta F, El-Beshlawy A (2010) The safety, tolerability, and efficacy of a liquid formulation of deferiprone in young children with transfusional iron overload. J Pediatr Hematol Oncol 32: 601-605.

68. Hoffbrand AV, Cohen A, Hershko C (2003) Role of deferiprone in chelation therapy for transfusional iron overload. Blood 102: 17-24. [Crossref]

69. De Domenico I1, Ward DM, Kaplan J (2009) Specific iron chelators determine the route of ferritin degradation. Blood 114: 4546-4551. [Crossref]

70. Bhandari S, Galanello R (2012) Renal aspects of thalassaemia a changing paradigm. Eur J Haematol 89: 187-197. [Crossref]

71. Chuang GT, Tsai IJ, Tsau YK, Lu MY (2015) Transfusion-dependent thalassaemic patients with renal Fanconi syndrome due to deferasirox use. Nephrology 20: 931-935.

72. Dee CM, Cheuk DK, Ha SY, Chiang AK, Chan GC (2014) Incidence of deferasiroxassociated renal tubular dysfunction in children and young adults with betathalassaemia. Br J Haematol 167: 434-436.

73. Dell'Orto VG, Bianchetti MG, Brazzola P (2013) Hyperchloraemic metabolic acidosis induced by the iron chelator deferasirox: a case report and review of the literature. Journal of clinical pharmacy and therapeutics 38:526-527.

74. Even-Or E, Becker-Cohen R, Miskin H (2010) Deferasirox treatment may be associated with reversible renal Fanconi syndrome. Am J Hematol 85: 132-134.

75. Grange S, Bertrand DM, Guerrot D, Eas F, Godin M (2010) Acute renal failure and Fanconi syndrome due to deferasirox. Nephrol Dial Transplant 25: 2376-2378.

76. Murphy N, Elramah M, Vats H, Zhong W, Chan MR (2013) A case report of deferasiroxinduced kidney injury and Fanconi syndrome 112: 177-180.

77. Papadopoulos N, Vasiliki A, Aloizos G, Tapinis P, Kikilas A (2010) Hyperchloremic metabolic acidosis due to deferasirox in a patient with beta thalassemia major. Ann Pharmacother 44: 219-221.

78. Rafat C, Fakhouri F, Ribeil JA, Delarue R, Le Quintrec M (2009) Fanconi syndrome due to deferasirox. Am J Kidney Dis 54: 931-934.

79. Rheault MN, Bechtel H, Neglia JP, Kashtan CE (2011) Reversible Fanconi syndrome in a pediatric patient on deferasirox. Pediatr Blood Cancer 56: 674-676.

80. Wei HY, Yang CP, Cheng CH, Lo FS (2011) Fanconi syndrome in a patient with betathalassemia major after using deferasirox for 27 months. Transfusion 51: 949-954.

81. Yacobovich J, Stark P, Barzilai-Birenbaum S, Krause I, Pazgal I, et al. (2010) Acquired proximal renal tubular dysfunction in beta-thalassemia patients treated with deferasirox. J Pediatr Hematol Oncol 32: 564-567.

82. Cappellini MD, Cohen A, Piga A, Bejaoui M, Perrotta S, et al. (2006) A phase 3 study of deferasirox (ICL670), a once-daily oral iron chelator, in patients with beta-thalassemia. Blood 107: 3455-3462. [Crossref]
83. Cappellini MD, Bejaoui M, Agaoglu L, Canatan D, Capra M, et al. (2011) Iron chelation with deferasirox in adult and pediatric patients with thalassemia major: efficacy and safety during 5 years' follow-up. Blood 118: 884-893. [Crossref]

84. Papneja K, Bhatt MD, Kirby-Allen M, Arora S, Wiernikowski JT, et al. (2016) Fancon Syndrome Secondary to Deferasirox in Diamond-Blackfan Anemia: Case Serie and Recommendations for Early Diagnosis. Pediatr Blood Cancer 63: 1480-1483. [Crossref]

85. Tunc B, Tavil B, Karakurt N, Yarali N, Azik FM, et al. (2012) Deferasirox therapy in children with Fanconi aplastic anemia. J Pediatr Hematol Oncol 34: 247-251.

86. Shah L, Powell JL, Zaritsky JJ (2017) A case of Fanconi syndrome due to a deferasirox overdose and a trial of plasmapheresis. J Clin Pharm Ther 42: 634-637. [Crossref]

87. Wong P, Polkinghorne K, Kerr PG, Doery JC, Gillespie MT, et al. (2016) Deferasirox at therapeutic doses is associated with dose-dependent hypercalciuria. Bone 85: 55-58. [Crossref]

88. Efthimia V, Neokleous N, Agapidou A, Economou M, Vetsiou E, et al. (2013) Nephrolithiasis in beta thalassemia major patients treated with deferasirox: an advent or an adverse event? A single Greek center experience. Ann Hematol 92: 263-265. [Crossref]

89. Beydoun HG1, Saliba AN2, Taher AT3 (2016) Deferasirox in thalassemia patients with end-stage renal disease. Am J Hematol 91: E456-457. [Crossref]

90. Karimi M, Avazpour A, Haghpanah S, Toosi F, Badie A (2017) Evaluation of Proteinuria in beta-Thalassemia Major Patients With and Without Diabetes Mellitus Taking Deferasirox. J Pediatr Hematol Oncol 39: e11-e4.

91. Brittenham GM (2011) Iron-chelating therapy for transfusional iron overload. N Eng/ J Med 364: 146-156. [Crossref]

92. Prasannan L, Flynn JT, Levine JE (2003) Acute renal failure following deferoxamine overdose. Pediatric nephrology 18: 283-285.

93. Aydinok Y, Coker C, Kavakli K, Polat A, Nisli G, et al. (1999) Urinary zinc excretion and zinc status of patients with beta-thalassemia major. Biol Trace Elem Res 70: 165172. [Crossref]

94. Adamkiewicz TV, Berkovitch M, Krishnan C, Polsinelli C, Kermack D, et al. (1998) Infection due to Yersinia enterocolitica in a series of patients with beta-thalassemia: incidence and predisposing factors. Clin Infect Dis 27: 1362-1366.

95. Chan GC, Chan S, Ho PL, Ha SY (2009) Effects of chelators (deferoxamine, deferiprone and deferasirox) on the growth of Klebsiella pneumoniae and Aeromonas hydrophila isolated from transfusion-dependent thalassemia patients. Hemoglobin 33 352-360. [Crossref]

96. Boelaert JR, de Locht M, Van Cutsem J, Kerrels V, Cantinieaux B, et al. (1993) Mucormycosis during deferoxamine therapy is a siderophore-mediated infection. In vitro and in vivo animal studies. J Clin Invest 91: 1979-1986. [Crossref]

97. Vichinsky E (2008) Clinical application of deferasirox: practical patient management Am J Hematol 83: 398-402. [Crossref]

Copyright: (C2018 Demosthenous C. This is an open-access article distributed under the terms of the Creative Commons Attribution License, which permits unrestricted use, distribution, and reproduction in any medium, provided the original author and source are credited. 